Agro-Science Journal of Tropical Agriculture, Food, Environment and Extension Volume 13 Number 3 September 2014 pp. 15 - 23

ISSN III9-7455

\title{
FIELD REACTIONS OF INTERSPECIFIC HYBRIDS OF TOMATO (SOLANUM LYCOPERSICON MILL.) LINES TO LEAF SPOT DISEASE
}

\author{
Amaefula, C . Agbo, C. U*. and Echezona, B. C. and Nwofia, G.E. ${ }^{2}$ \\ Department of Crop Science, University of Nigeria, Nsukka. \\ *Corresponding author e-mail: christian.agbo@unn.edu.ng
}

\begin{abstract}
Leaf spot is a major disease of tomato causing reduction in fruit yield under humid environments. It's control using some of the major systemic fungicides available is environmentally unfriendly and costly. Heterosis known to increase productivity in crops was used to assess improvement in tomato yield and resistance to leaf spot disease. Crosses were made on four selected parent plants in a diallel fashion in 2011. Seedlings of the parent plants and their resulting hybrids were established in a field in a randomized complete block design with three replications in 2012. The leaves were assayed at the vegetative and reproductive stages for leaf spot infection and some phytochemicals content. Data obtained were subjected to analysis of variance, correlation and path analysis to partition the effects to the causes. Better parent heterosis $(\mathrm{BPH})$ was obtained at both stages of growth. The disease incidence and severity amongst the hybrids were significantly $(p=0.05)$ reduced in all crosses with wild as the pistillate parent relative to others. The hybrid, wild $x$ petomech $(W x P)$ had significantly higher phenol content of $4.29 \mathrm{mg} / 100 \mathrm{~g}$, highest negative BPH of $-30.40 \%$ and lower in disease severity. Flavonoid showed a positive and significant correlation with phenol $(r=0.51, n=39, p=0.01)$. There was a high direct $(0.98)$ and indirect (1.0) effects of flavonoid to fruit yield through disease severity at fruit ripening. The hybrids, $W x P$ and wild $x$ insulata could be selected as they had less leaf spot disease severity and high fruit yield.
\end{abstract}

Keywords: disease incidence, disease severity, heterosis, phytochemicals and wild tomato

\section{INTRODUCTION}

Tomato (Solanum lycopersicum Mill.) is one of the most important vegetables in Nigeria. It is an excellent source of vitamins, minerals and phytochemicals that contribute to the health or prevention of prostate cancer in humans (Edinger et al., 2008). Tomato fruits are consumed fresh in salads or cooked in sauces. It is grown in many parts of Nigeria both as wet and dry season crops (Wokoma, 2008). The bulk of tomato production in Nigeria comes from the Northern states. This is due to the presence of enabling environmental conditions such as; low rainfall, diurnal range in temperature, relatively dry climate, low relative humidity, low pest and disease incidence which allows the growth and development of the crop in the region. Tomato crops grown in Northern Nigeria have higher yields and better quality fruits (Wokoma, 2008). In south eastern Nigeria, production of tomato is mainly at a small scale in backyard gardens. Reduction in the number of flowers as a result of flower abscission in high rainfall environment could be considered as a major problem in tomato production (Weerakkody and
Peiris, 1997). Diseases constitute a serious limiting factor to tomato production in Nigeria (Wokoma, 2008). Such diseases as fungal leaf spots, mould, damping off and blossom end rot that proliferate under high humidity and insufficient drainage would cause yield and quality losses in tomato plant (Hessayon 1985; Naika et al. 2005). Foliage diseases are rampant at high temperature and high relative humidity and often increase losses in terms of yield (Uguru \& Igili, 2002; Naika, et al. 2005). Some of the major leaf spots (foliage) diseases of tomato in southern Nigeria are Septoria and Cercospora leaf spots, caused by the fungi Septoria lycopersici and Cercospora spp., respectively. The spread of the diseases is encouraged by excessive rainfall and high temperature. The disease causing organism is most destructive during wet weather (Yang, 1978). Uguru \& Atugwu (2001) observed low performance and low fruit set in tomato in South Eastern Nigeria due to excessive flower and premature abortion with high correlation to severe leaf spot disease. Erinle (1979) had ealier reported low yields in 
tomato in humid areas mostly due to Septoria diseases on the plant. Intense disease activity of the leaf spots causes extensive yellowing, withering or defoliation of canopy and subsequent loss of crop vigour (Elliott and Harmon, 2011).

Anon. (2014) reported that leaf spots are difficult to manage because they do not respond to some of the available fungicides that are also environmentally unfriendly and costly. The development of a resistant genotype with heterotic potentials will be a sure way to overcome leaf spot diseases as has been exemplified by Brooklyn Botanic Garden (2000) in natural disease control. The wild tomato variety Lycopersicon pimpinellifolium (L.) Mill. has been found to have good tolerance to heavy rainfall, high humidity, drought conditions and diseases infection. It remains a good source of gene for wide adaptability, improvement of fruit quality and disease resistance to common foliage diseases of tomato.

Plants have been found to produce some chemical compounds (phytochemicals) which protect them against pathogens and herbivore (Wittstock \& Gershenzon 2002). For example, Phenols have been found to offer resistance to plants against disease infections (Sadasivam \& Manickam 1992). Most of them have antimicrobial activity (Kondo \& Kawashima 2000).

The objectives of the study were to determine the level of disease incidence, severity and phytochemical content of some tomato parents and hybrids derived from inter-specific hybridization. Also, to quantify heterosis effects of the tomato hybrid traits/components on disease variables and improvement in fruit yield in the leaf spot endemic area.

\section{Materials and methods}

The experiment was conducted at the Department of Crop Science Teaching and Research Farm, University of Nigeria, Nsukka. Seeds of three exotic tomato varieties (Petomech, Grosso and Insulata) that are high yielding but highly susceptible to leaf spot and a wild species (Lycopersicon pimpinellifolium (L.) Mill.) with small fruits but resistant to leaf spot disease were selected from the previous years' cropping in 2011. These were sown in nursery baskets containing mixtures of top soil, well cured manure and river sand in a ratio of 3: 2: 1 , respectively. Seedlings were transplanted 4 weeks after planting to a field measuring $624 \mathrm{~m}^{2}$ and laid out in a randomized complete block design with three replications. Each block contained 13 plots. The blocks and plots were separated by $1 \mathrm{~m}$ wide path. The seedlings were transplanted at a spacing of 1 $\mathrm{m} \times 0.5 \mathrm{~m}$ into plots; each plot measuring $5 \mathrm{~m} \mathrm{x} 2 \mathrm{~m}$ with a population of 20 plants. All cultural practices, were carried out as and at when due. Crosses were made on the four selected parent plants in a diallel fashion in 2011 and the seeds processed and used to raise $F_{1}$ seedlings in 2012. Seedlings of the four parent plants and their six resulting hybrids and three selected reciprocals were established in a field in a randomized complete block design with three replications in 2012 as was done the previous year. The leaves of the parents and the hybrids were assayed at the vegetative and reproductive stages for leaf spot disease and some phytochemicals (tannin, phenol, flavonoids and alkaloid) contents in 2012. Data were also collected at the two growth stages on plant height, number of fruits/plant, and fruit yield. The disease severity was estimated on six middle plants using the formular.

Disease severity $=\frac{\text { area of diseased tissue }}{\text { total tissue area }} \times 100$ (

Cooke, 1998))

Grade values were allotted depending upon the area of infection. Disease severity was assessed using a scale of 0 - 5 where; $0=$ no damage, $1=$ mild, $2=$ less severe, $3=$ severe, $4=$ moderately severe and $5=$ very severe (Tarr, 1981).

Disease incidence was calculated purposively on the 20 plants using Cohen et al. (2000) formula:

Disease incidence $=$ $\frac{\text { number of infected plants }}{\text { total number of the plants assessed }} \times 100$

Data obtained were subjected to analysis of variance using Genstat Release 10.3 DE (2011). Means were compared using Fisher's least significant difference (FLSD) for randomized complete block design as outlined by Obi (2002).

Better parent heterosis was calculated as out lined by Acquaah (2007) as:

$\mathrm{BPH} \%=\frac{\overline{F_{1}}-\overline{B P}}{\overline{B P}} \times 100$

where:

$\overline{F_{1}}=$ mean of First filial generation

$\overline{B P}=$ mean of the better parent

Correlation of the traits was done using SPSS version 16. The variables were partitioned into their direct and indirect contributions to disease index using path analysis (Dewey and Lu, 1959).

\section{Phytochemical Assay of the tomato leaves. Alkaloid}

The method of Harbone (1973) was used. To each of $2 \mathrm{~g}$ of the leaf extract was added about $80 \mathrm{ml}$ of $10 \%$ acetic acid in ethanol. The beakers were labeled appropriately. The solutions were covered and allowed to stand for 4 hours. Solutions were later filtered with filter papers and the filtrate collected and labeled appropriately. About $10 \mathrm{ml}$ of $\mathrm{NH}_{4} \mathrm{OH}$ solution was 
added to each filtrate to precipitate the alkaloid. The precipitates were then allowed to stand for one hour. The filtrates were finally re- filtered with weighed filter paper and labeled. The filter papers were air dried to constant weight. The new weight was noted accordingly.

The concentration of alkaloid was calculated using the formula:

$\%$ (weight of filter paper+alkaloid)-weight of filter p weight of sample used

\section{Total phenol.}

The method described by Harbone (1973) was used to determine total phenol. A $10 \mathrm{ml}$ of ether was added to each of the flasks containing $2 \mathrm{~g}$ of the extracts to defat the samples. They were filtered. The filtrates were discarded while the residues were air dried for few minutes. The dried residues were later boiled with 50 $\mathrm{ml}$ of ether each for the extraction of the phenol component for 15 minutes. Boiled aliquot $(5 \mathrm{ml})$ was taken from each of the sample solution after cooling. In the same vein, then $5 \mathrm{ml}$ of ether was also pipetted as blank. All the aliquots were put in test tubes. Each test tube received $10 \mathrm{ml}$ of distilled water, $2 \mathrm{ml}$ of $\mathrm{NH}_{4} \mathrm{OH}$ solution and $5 \mathrm{ml}$ of amyl alcohol in sequential order. The solutions were allowed for 30 minutes for colour development. The blank was used to zero down the spectrometer at $470 \mathrm{~nm}$ wavelength. The upper portion of the solutions of all the samples was pipetted out and the readings were made at the same wavelength using spectrophotometer. The samples were replicated three times.

The concentration of the phenol in the samples was calculated using the standard phenol reading.

Phenol (mg/100

$=$

absorbance of sample

absorbance of standard

Tannin

The Pearson (1976) method was used in this experiment to determine the tannin content of the tomato leaves. A $50 \mathrm{ml}$ of distilled water was added to each beaker containing $2 \mathrm{~g}$ of the samples. This was allowed to stand for 30 minute at room temperature with gentle shaking at every 5 minutes interval. This was centrifuged and then filtered. About $2.5 \mathrm{ml}$ of the aliquot was taken from each of the solution and transferred into labeled test tubes. Similarly, $2.5 \mathrm{ml}$ of distilled water was measured as blank. Each of the test tubes received $1 \mathrm{ml}$ of folin-denis reagent. The volumes were made up to $5 \mathrm{ml}$ each by adding additional $1.5 \mathrm{ml}$ of distilled water and the solutions were incubated for 90 minutes at room temperature. The blank prepared was used to zero down the spectrophotometer. The readings from spectrophotometer were made immediately at $530 \mathrm{~nm}$ wavelength. Concentration of tannin was calculated using the formula:

Concentration of Tannin $=$

$\frac{\text { absorbance of sample }}{\text { absorbance of standard }} \times$ concentration of standard

\section{Flavonoid}

Percentagegflavonoid was determined using Boham and Kocipai (1974) method. A $10 \mathrm{~g}$ of each of the samples was weighed; $100 \mathrm{ml}$ of $80 \%$ aqueous methanol at room temperature was then added to the samples. The solutions were filtered through Whatman filter paper No $42(125 \mathrm{~mm})$. The filtrates were then transferred into a weighed crucible and made to dry by evaporation. The crucible was then reweighed to a constant weight. Percentage flavonoid was calculated as follows:

$$
\% \text { Flavonoid }=\frac{\text { weight of flavonoid }}{\text { total weight used }} \times 100
$$

\section{RESULTS}

The hybrids wild $\mathrm{x}$ insulata (W $\mathrm{x}$ In) and wild $\mathrm{x}$ petomech $(\mathrm{W} \times \mathrm{P})$ had significantly $(\mathrm{p}=0.05)$ taller plants of $38 \mathrm{~cm}$ and $198 \mathrm{~cm}$ at one month of growth and fruit ripening stages, respectively (Table 1). Most of the hybrids were significantly $(\mathrm{p}=0.05)$ taller relative to their respective parents at both stages of growth. Grosso x petomech $(\mathrm{G} \times \mathrm{P})$ and grosso $\mathrm{x}$ wild (G x W) (reciprocal) hybrids showed significantly lower plant heights of $100.2 \mathrm{~cm}$ and $18.7 \mathrm{~cm}$ at the respective growth stages. The number of fruits/plant was significantly $(p=0.05)$ higher among the wild parents compared to other parents or their hybrids. All cases where wild served as the parent produced significantly $(p=0.05)$ more number of fruits than other hybrids or where the wild was the staminate. Crosses with wild as the pistillate produced significantly $(\mathrm{p}=0.05)$ higher fruit yield compared to the reciprocals or other parents.

The incidence and severity of leaf spot disease symptom at one month after planting and at fruit ripening were significantly $(\mathrm{p}=0.05)$ lower amongst the wild parent compared to other parents (Table 2). All the hybrids except $\mathrm{G} \times \mathrm{P}$ and $\mathrm{P} \times \mathrm{W}$ significantly (p $=0.05)$ suppressed the incidence and severity of the disease symptom compared to their respective parents, except in the wild parent. The disease incidence and severity amongst the hybrids were significantly $(\mathrm{p}=$ 0.05 ) reduced in all crosses where the wild served as the pistillate parent relative to other hybrids.

Petomech parent was significantly higher in alkaloid than the other parents and hybrids (Table 3). The 
hybrid, In x W (3.04\%) was significantly ( $\mathrm{p}=0.05)$ lower than the other hybrids and parents in alkaloid content. The hybrid, In X P was significantly $(p=0.05)$ lower in Flavonoid content $(1.97 \%)$ than all the other hybrids and the parents though it was statistically similar to $\mathrm{G} \times \mathrm{P}(1.99 \%), \mathrm{W} \times \mathrm{G}(1.98 \%)$ and the wild parent $(1.99 \%)$. The hybrid, W x P had significantly higher Phenol content $(4.29 \mathrm{mg} / 100 \mathrm{~g})$ than all the other hybrids. The Grosso parent had significantly lower phenol content $(1.00 \mathrm{mg} / 100 \mathrm{~g})$ than the other parents and hybrids. The hybrid, $\mathrm{G} \times \mathrm{P}$ had significantly lower tannin content of $0.078 \%$ than the other hybrids and parents at one month after planting though it was statistically similar to Grosso $(0.095 \%)$, Insulata (0.094 \%), In x P (0.094\%), and Petomech $(0.094 \%)$. The hybrid, In x G had significantly higher tannin content $(0.397 \%)$ than all the other hybrids and parents.

Table 1: Agronomic and yield traits attributes of the tomato parents and hybrids

\begin{tabular}{|c|c|c|c|c|c|c|}
\hline Entries & H 1MAP & H R & SG1MAP & SG R & Frts/plt & FY(t/ha) \\
\hline \multicolumn{7}{|l|}{ Parents } \\
\hline GRS & 21.03 & 114.40 & 15.33 & 41.65 & 2.60 & 1.86 \\
\hline РETO & 20.13 & 62.70 & 13.84 & 47.97 & 7.60 & 1.98 \\
\hline INS & 24.13 & 104.80 & 11.20 & 43.77 & 3.70 & 1.26 \\
\hline WILD & 23.84 & 149.50 & 10.93 & 24.69 & 709.20 & 5.98 \\
\hline \multicolumn{7}{|l|}{ Half diallel } \\
\hline In $x \mathrm{G}$ & 25.84 & 136.80 & 12.00 & 37.15 & 2.83 & 2.53 \\
\hline W x G & 29.71 & 167.70 & 12.63 & 34.47 & 227 & 10.28 \\
\hline W x In & 38.02 & 196.30 & 12.27 & 35.13 & 273 & 18.86 \\
\hline$G \times P$ & 25.89 & 100.20 & 10.76 & 36.29 & 3.33 & 1.32 \\
\hline In $x \mathrm{P}$ & 23.27 & 116.80 & 14.03 & 48.03 & 7.25 & 3.17 \\
\hline $\mathrm{W} \times \mathrm{P}$ & 32.84 & 198.20 & 13.33 & 36.85 & 438.33 & 27.41 \\
\hline \multicolumn{7}{|l|}{ Reciprocals } \\
\hline $\mathrm{G} \times \mathrm{W}$ & 18.77 & 167.70 & 14.38 & 32.80 & 96.67 & 3.80 \\
\hline In $x$ W & 25.72 & 171.00 & 14.31 & 33.88 & 89.33 & 2.92 \\
\hline $\mathrm{P} \times \mathrm{W}$ & 22.86 & 105.50 & 13.86 & 32.99 & 36.67 & 1.39 \\
\hline F- $\operatorname{LSD}(0.05)$ & 2.86 & 12.30 & 2.34 & 3.43 & 5.44 & 3.67 \\
\hline
\end{tabular}

where: INS= Insulata; GRS= Grosso; PET= Petomech; In x P= Insulata $\times$ Petomech; In $x$ G= Insulata $x$ Grosso; In $x$ W= Insulata $x$ Wild; W x $\mathrm{G}=$ wild x Grosso; W x In = Wild x Insulata; W x P= Wild x Petomech; G x W= Grosso x Wild; G x P= Grosso x Petomech; P x W= Petomech x Wild; $\mathrm{H} 1 \mathrm{MAP}=$ height $(\mathrm{cm})$ at 1 month after planting; $\mathrm{H} \mathrm{R}=$ height $(\mathrm{cm})$ at fruit ripening; $\mathrm{SG} 1 \mathrm{MAP}=\operatorname{stem}$ girth $(\mathrm{mm})$ at one month; $\mathrm{SG} \mathrm{R}=\mathrm{stem}$ $\operatorname{girth}(\mathrm{mm})$ at fruit ripening; Frts/plt= number of fruits/plant; FY= fruit yield.

Table 2: Disease incidence and severity at one MAP, fruit ripening, and fruit yield of the tomato parents and hybrids

\begin{tabular}{|c|c|c|c|c|c|}
\hline \multirow{2}{*}{ Entries } & \multicolumn{2}{|l|}{ Incidence (\%) } & \multicolumn{2}{|c|}{ Severity $(\%)$} & \multirow[b]{2}{*}{ FY(t/ha) } \\
\hline & 1MAP & Fruit ripening & 1MAP & Fruit ripening & \\
\hline \multicolumn{6}{|l|}{ Parents } \\
\hline GRS & $88.33(9.42)$ & $100.0(10.02)$ & $4.67(2.27)$ & $5.00(2.35)$ & 1.86 \\
\hline PET & $85.00(9.24)$ & $91.70(9.60)$ & $4.67(2.27)$ & $4.67(2.27)$ & 1.98 \\
\hline INS & $93.33(9.69)$ & $95.80(9.81)$ & $4.67(2.27)$ & $5.00(2.35)$ & 1.26 \\
\hline WILD & $4.67(2.27)$ & $26.40(5.12)$ & $1.33(1.34)$ & $2.00(1.58)$ & 5.98 \\
\hline \multicolumn{6}{|l|}{ Half diallel } \\
\hline In $x \mathrm{G}$ & $4.67(2.27)$ & $88.90(9.42)$ & $1.33(1.34)$ & $4.67(2.27)$ & 2.53 \\
\hline $\mathrm{W} \times \mathrm{G}$ & $4.00(2.11)$ & $50.00(6.86)$ & $1.67(1.46)$ & $3.00(1.86)$ & 10.28 \\
\hline W x In & $0.00(0.71)$ & $56.50(7.34)$ & $0.00(0.71)$ & $3.33(1.94)$ & 18.86 \\
\hline$G \times P$ & $0.00(0.71)$ & $87.50(9.36)$ & $0.00(0.71)$ & $4.33(2.19)$ & 1.32 \\
\hline In $\times \mathrm{P}$ & $26.67(5.19)$ & $78.60(8.89)$ & $2.67(1.77)$ & $4.33(2.19)$ & 3.17 \\
\hline $\mathrm{W} \times \mathrm{P}$ & $2.33(1.68)$ & $50.00(6.86)$ & $1.33(1.34)$ & $2.00(1.58)$ & 27.41 \\
\hline \multicolumn{6}{|l|}{ Reciprocals } \\
\hline In $\mathrm{X} W$ & $0.00(0.71)$ & $44.40(6.68)$ & $0.00(0.71)$ & $2.67(1.77)$ & 2.92 \\
\hline $\mathrm{P} \times \mathrm{W}$ & $36.67(6.08)$ & $39.90(6.10)$ & $2.00(1.68)$ & $2.33(1.66)$ & 1.39 \\
\hline F-LSD $(0.05)$ & $6.75(0.49)$ & $29.39(2.14)$ & $0.71(0.22)$ & $1.32(0.35)$ & 3.67 \\
\hline
\end{tabular}

where: INS= Insulata; GRS= Grosso; PET= Petomech; In $\times \mathrm{P}=$ Insulata $\times$ Petomech; In $\times \mathrm{G}=$ Insulata $\times \mathrm{Grosso}$; In $\times$ W= Insulata $\times$ Wild; W $\mathrm{x}$ $\mathrm{G}=$ wild $\times$ Grosso; W x In = Wild x Insulata; W x P= Wild x Petomech; G x W= Grosso x Wild; G x P= Grosso x Petomech; P x W= Petomech x Wild; FY= fruit yield; $1 \mathrm{MAP}=1$ month after planting; values in parenthesis are transformed data. 
Better parent heterosis (BPH) of the disease incidence showed that all the hybrids had negative $\mathrm{BPH}$ in disease incidence at one month after planting (Table 4). The highest negative BPH of $92.7 \%$ was observed in both $\mathrm{In} \times \mathrm{W}$ and its reciprocal (W $\mathrm{x}$ In) for disease incidence at one MAP. The lowest negative BPH was recorded in $\mathrm{P} \times \mathrm{W}(-34.10 \%)$ in disease incidence at one MAP. Negative BPH was recorded for all the hybrids in disease incidence at fruit ripening. The highest negative $\mathrm{BPH}$ was recorded for the hybrid, $\mathrm{G} \times$ $\mathrm{W}(-40.0 \%)$ at fruit ripening. The hybrid, In $\mathrm{x} G$ showed the lowest negative BPH $(-3.9 \%)$ for disease incidence at fruit ripening.

BPH of disease severity showed that all the hybrids had negative BPH in disease severity at one month after planting. The hybrid, W $x$ In and the reciprocal, In $\mathrm{x}$ W with $\mathrm{BPH}$ of $-69.9 \%$ had the highest negative value. The hybrid, In x P had the lowest negative BPH of $24.30 \%$. The BPH of disease severity at fruit ripening showed that the hybrid, $\mathrm{W} \times \mathrm{P}$ had the highest negative $\mathrm{BPH}$ of $-30.40 \%$. The hybrid, In $\mathrm{x} \mathrm{P}$ had the lowest $\mathrm{BPH}$ of $-3.30 \%$.

Table 3: Concentration of some phytochemicals on the leaves of the tomato parents and hybrids at one month after planting.

\begin{tabular}{lllll} 
Entries & Alkaloid(\%) & Flavonoid (\%) & $\begin{array}{l}\text { Phenol } \\
(\mathbf{m g} / \mathbf{1 0 0 g})\end{array}$ & Tannin (\%) \\
\hline Parents & & & & \\
\hline GRS & 6.03 & 2.00 & 1.01 & 0.095 \\
PET & 8.61 & 2.41 & 2.74 & 0.094 \\
INS & 3.66 & 2.47 & 2.26 & 0.094 \\
WILD & 3.42 & 1.99 & 2.16 & 0.105 \\
Half diallel & & & & \\
In x G & 5.45 & 2.47 & 1.00 & 0.397 \\
W x G & 5.36 & 1.98 & 1.03 & 0.104 \\
W x In & 5.62 & 2.54 & 2.36 & 0.124 \\
G x P & 5.91 & 1.99 & 2.26 & 0.078 \\
In x P & 7.14 & 1.97 & 2.23 & 0.094 \\
W x P & 4.72 & 2.62 & 4.29 & 0.124 \\
Reciprocals & & & & \\
G x W & 3.94 & 2.49 & 2.14 & 0.105 \\
In x W & 3.04 & 2.97 & 3.14 & 0.114 \\
P x W & 6.34 & 2.47 & 1.57 & 0.126 \\
F-LSD (0.05) & 0.99 & 0.083 & 0.023 & 0.24 \\
\hline Whe INS= & & & \\
\hline
\end{tabular}

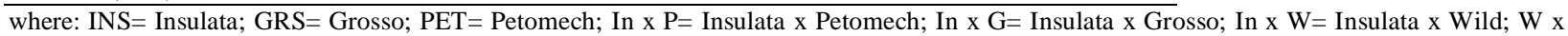
G= wild x Grosso; W x In = Wild x Insulata; W x P= Wild x Petomech; G x W= Grosso x Wild; G x P= Grosso x Petomech; P x W= Petomech x Wild.

Table 4: Estimates of the Better parent heterosis (BPH) for disease incidence and severity.

\begin{tabular}{|c|c|c|c|c|}
\hline Genotypes & Incidence at 1MAP (\%) & $\begin{array}{l}\text { Incidence at fruit } \\
\text { ripening }(\%)\end{array}$ & Severity at $1 \mathrm{MAP}(\%)$ & $\begin{array}{l}\text { Severity at fruit } \\
\text { ripening }(\%)\end{array}$ \\
\hline \multicolumn{5}{|l|}{ Half diallel } \\
\hline In $\times$ G & -76.55 & -3.90 & -42.70 & 0.00 \\
\hline W x G & -77.50 & -31.50 & -35.60 & -17.20 \\
\hline W x In & -92.70 & -25.20 & -69.90 & -14.50 \\
\hline $\mathrm{G} \times \mathrm{P}$ & -92.50 & -6.60 & -68.90 & -3.70 \\
\hline In $x$ P & -46.40 & -9.40 & -24.30 & -3.30 \\
\hline $\mathrm{W} \times \mathrm{P}$ & -81.80 & -28.50 & -40.80 & -30.40 \\
\hline \multicolumn{5}{|l|}{ Reciprocals } \\
\hline $\mathrm{G} \times \mathrm{W}$ & -92.50 & -40.00 & -68.90 & -21.60 \\
\hline In $x$ W & -92.70 & -32.50 & -69.90 & -21.90 \\
\hline $\mathrm{P} \times \mathrm{W}$ & -34.10 & -36.50 & -30.40 & -27.10 \\
\hline $\mathrm{SE}$ & 0.29 & 1.27 & 0.13 & 0.21 \\
\hline $\mathrm{CD}(0.05)$ & 0.61 & 2.67 & 0.28 & 0.44 \\
\hline
\end{tabular}


Better Parent Heterosis (BPH) of some phytochemicals of the tomatoes used for the study showed that the The hybrid, $\mathrm{W} \times \mathrm{P}$ on the other hand, had the lowest BPH of $-45.18 \%$ in alkaloid content. The hybrid, G x $\mathrm{W}$ had the highest BPH of $24.5 \%$ in flavonoid. On the other hand, the hybrid, In x P had the lowest BPH of $20.24 \%$ in the phytochemical. The hybrid, W x P had the highest BPH in phenol content $(56.57 \%)$. The lowest BPH in Phenol content was recorded in the hybrid, In x G (-55.75\%). In tannin, the hybrid In x G had the highest BPH of $317 \%$. The lowest BPH of $17.89 \%$ was recorded in $\mathrm{G} \times \mathrm{P}$ in tannin content.

The correlation coefficients of the tomato crop attributes and disease severity showed that the level of leaf spot incidence at one month and ripening stages had the highest positive correlation with disease severity at the same period $(r=0.93 ; 0.93$, respectively hybrid, W x In had the highest BPH of $53.55 \%$ in alkaloid content (Table 5). $\mathrm{n}=39, \mathrm{p}=0.01)$. The level of phenol compound in the leaves of the genotypes showed a significant positive correlation of $(r=0.75, n=39, p=0.01)$ with fruit yield. Plant height at ripening showed a significant positive correlation of $(\mathrm{r}=0.71, \mathrm{n}=39, \mathrm{p}=0.01)$ to fruit yield. Flavonoid showed a positive and significant correlation with $(\mathrm{r}=0.51, \mathrm{n}=39, \mathrm{p}=0.01)$ phenol. Alkaloid showed positive correlation with disease incidence and severity at one month and at ripening stages. On the other hand, plant height at ripening showed a negative and significant correlation with disease incidence and severity at ripening $(r=-0.73$; 0.54 , respectively, $\mathrm{n}=39, \mathrm{p}=0.01$ ). Number of fruits showed positive correlation of $(\mathrm{r}=0.56, \mathrm{n}=39, \mathrm{p}=$ 0.01 ) with plant height at ripening.

Table 5: Estimates of the Better Parent Heterosis (BPH) of some phytochemical analysis of the tomato leaves.

\begin{tabular}{lllll}
\hline Genotypes & Alkaloid (\%) & Flavonoid (\%) & Phenol (\%) & Tannin (\%) \\
\hline Half diallel & & & & \\
\hline In x G & -7.62 & 0.00 & -55.57 & 317.89 \\
W x G & -11.11 & -1.00 & -52.31 & -0.95 \\
W x In & 53.55 & 2.83 & 4.42 & 18.09 \\
G x P & -31.36 & -17.43 & -17.52 & -17.89 \\
In x P & -17.07 & -20.24 & -18.61 & 0.00 \\
W x P & -45.18 & 8.71 & 56.57 & 18.09 \\
Reciprocals & & & & \\
G x W & 34.66 & 24.50 & -0.93 & 0.00 \\
In x W & 16.94 & 20.24 & 38.94 & 8.57 \\
P x W & -26.40 & 2.49 & -42.70 & 20.00 \\
SE & 0.05 & 0.04 & 0.01 & 0.12 \\
CD (p=0.05) & 0.10 & 0.08 & 0.02 & 0.24 \\
\hline
\end{tabular}

where: In $x$ P= Insulata $x$ Petomech; In x G= Insulata x Grosso; In x W= Insulata x Wild; W x G= wild x Grosso; W x In = Wild x Insulata; W x P= Wild x Petomech; G x W= Grosso x Wild; G x P= Grosso x Petomech; P x W= Petomech x Wild; S E= standard error; $\mathrm{CD}=$ critical difference.

Table 6: The correlation coefficients of the tomato crop attributes, disease severity and phytochemicals studied

\begin{tabular}{|c|c|c|c|c|c|c|c|c|c|c|c|}
\hline Traits & $\begin{array}{l}\text { Inc } \\
1 \mathrm{MAP}\end{array}$ & Inc $\mathrm{R}$ & $\begin{array}{l}\text { Sev } \\
1 \mathrm{MAP}\end{array}$ & Sev R & Tannin & Alkaloid & phenol & flavonoid & FY & Nfrt/plt & $\begin{array}{l}\text { height } \\
\text { ripe }\end{array}$ \\
\hline Inc 1MAP & 1 & & & & & & & & & & \\
\hline Inc $\mathrm{R}$ & $0.481 * *$ & 1 & & & & & & & & & \\
\hline Sev 1MAP & $0.930 * *$ & $0.456 * *$ & 1 & & & & & & & & \\
\hline Sev R & $0.470 * *$ & $0.932 * *$ & $0.429 * *$ & 1 & & & & & & & \\
\hline Tannin & -0.103 & 0.125 & 0.013 & 0.121 & 1 & & & & & & \\
\hline Alkaloid & $0.434 * *$ & $0.411 * *$ & $0.410 * *$ & $0.413 * *$ & -0.013 & 1 & & & & & \\
\hline Phenol & -0.221 & -0.162 & -0.216 & $-0.334 *$ & -0.182 & -0.18 & 1 & & & & \\
\hline Flavonoid & -0.182 & -0.170 & -0.284 & -0.247 & 0.127 & $-0.336 *$ & $0.509 * *$ & 1 & & & \\
\hline FY & $-0.435 * *$ & $-0.353 *$ & $-0.349 *$ & $-0.506 * *$ & -0.030 & $-0.451 * *$ & $0.750 * *$ & $0.536^{* * *}$ & 1 & & \\
\hline Nfrt/plt & $-0.433 * *$ & $-0.611 * *$ & -0.308 & $-0.650 * *$ & -0.072 & $-0.597 * *$ & $0.449 * *$ & 0.082 & $0.582 * *$ & 1 & \\
\hline height ripe & $-0.734 * *$ & $-0.509 * *$ & $-0.648 * *$ & $-0.537 * *$ & 0.049 & $-0.684 * *$ & $0.332^{*}$ & $0.423 * *$ & $0.710^{* * *}$ & $0.561 * *$ & 1 \\
\hline
\end{tabular}

where: Inc $1 \mathrm{MAP}=$ disease incidence at one month; Inc $\mathrm{R}=$ disease incidence at fruit ripening; Sev $1 \mathrm{MAP}=$ disease severity at one month; Sev R = disease severity at fruit ripening; Nfrt/plt= number of fruits/plant; $\mathrm{n}=39$. 
Amaefula, C . Agbo, C. U. and Echezona, B. C. and Nwofia, G.E.

Table 7: Direct (diagonal) and indirect effects of the disease incidence, severity, phytochemicals and growth attributes of the tomato varieties used for the study on the yield

\begin{tabular}{|c|c|c|c|c|c|c|c|c|c|c|c|}
\hline & $\begin{array}{l}\text { Inc } \\
\text { 1MAP }\end{array}$ & Inc $R$ & $\begin{array}{l}\text { Sev } \\
1 \mathrm{MAP}\end{array}$ & Sev R & Tannin & Alkaloid & Phenol & Flavonoid & Nfrt/plt & $\begin{array}{l}\text { height } \\
\text { ripe }\end{array}$ & $\begin{array}{l}\text { Corr } \\
\text { coeff. }\end{array}$ \\
\hline Inc 1MAP & -0.82 & 1.92 & -0.38 & -1.94 & 0.11 & 0.030 & 0.40 & -0.18 & -0.77 & 0.09 & -0.44 \\
\hline Inc $\mathrm{R}$ & -0.47 & 3.34 & -0.22 & -3.32 & -0.09 & 0.030 & 0.34 & -0.20 & -1.27 & 0.08 & -0.35 \\
\hline Sev 1MAP & -0.78 & 1.81 & -0.40 & -1.75 & 0.05 & 0.030 & 0.40 & -0.28 & -0.55 & 0.08 & -0.35 \\
\hline Sev R & -0.46 & 3.17 & -0.20 & -3.49 & -0.10 & 0.030 & 0.70 & -0.28 & -1.34 & 0.08 & -0.51 \\
\hline Tannin & 0.16 & 0.53 & 0.04 & -0.62 & -0.56 & -0.002 & 0.58 & 0.22 & -0.23 & -0.01 & -0.03 \\
\hline Alkaloid & -0.36 & 1.65 & -0.17 & -1.72 & 0.01 & 0.070 & 0.32 & -0.33 & -1.05 & 0.08 & -0.45 \\
\hline Phenol & 0.18 & -0.64 & 0.09 & 1.37 & 0.18 & -0.010 & -1.79 & 0.50 & 0.79 & -0.04 & 0.75 \\
\hline Flavonoid & 0.15 & -0.67 & 0.12 & 1.00 & -0.13 & -0.020 & -0.92 & 0.98 & 0.15 & -0.05 & 0.54 \\
\hline Nfrt/plt & 0.36 & -2.41 & 0.12 & 2.66 & 0.07 & -0.040 & -0.80 & 0.08 & 1.76 & -0.07 & 0.58 \\
\hline height ripe & 0.61 & -2.14 & 0.26 & 2.31 & -0.05 & -0.050 & -0.59 & 0.42 & 1.00 & -0.12 & 0.56 \\
\hline Residual (R) & & & & & & & & & & & 0.24 \\
\hline
\end{tabular}

where: Inc $1 \mathrm{MAP}=$ disease incidence at one month; Inc R= disease incidence at fruit ripening; Sev $1 \mathrm{MAP}=$ di sease severity at one month; Sev R = disease severity at fruit ripening; Nfrt/plt= number of fruits/plant.

Phenol had the strongest negative direct effect of -1.79 to fruit yield and positive indirect effect of 1.37 and 0.79 through severity at ripening and number of fruits/plant, respectively to fruit yield (Table 7). Number of fruits/plant showed positive high magnitude direct effect of 1.76 to fruit yield. High positive indirect effects of 2.66 and 2.31 to fruit yield were established by number of fruits/plant and plant height at ripening, respectively. Incidence of leaf spot disease at ripening showed strongest positive direct effect of 3.34 and negative indirect effect of 3.32 through severity at ripening to fruit yield. Flavonoids showed high magnitude positive direct effect of 0.98 and indirect effect of 1.0 to fruit yield through disease severity at fruit ripening.

\section{DISCUSSION}

The increase in fruit yield, plant height, and number of fruits/plant observed in the hybrids showed that there was heterosis in these traits studied. This result was in conformity with the findings of Dharmatti et al. (2006) and Sharma et al. (2001) who observed heterotic effect in fruit yield and number of fruits/ plant, respectively in tomato. The high number of fruits/plant recorded in the wild was attributed to more number of flowers/ truss and flowers/plant observed in the plant. This also led to higher fruit yield. The higher fruit yield recorded amongst hybrids having the wild as mother plant showed maternal effect of the wild parent on the offspring. The hybrids, W x G, P x W, G x W, In x W and $\mathrm{W} \times \mathrm{P}$ that had low disease incidence and severity at fruit ripening, showed that, the wild parent was able to transfer high resistant genes to these hybrids and improve the fruit yield and other traits. Heterotic effects of traits of other crop hybrids have been shown to increase yield in such crop species (Lavanya et al. 1997; Perez et al. 2009; Agbo et al. 2011). The high phenol $(4.29 \mathrm{mg} / 100 \mathrm{~g})$ and high flavonoid $(2.62 \%)$ content of $\mathrm{W} \times \mathrm{P}$ seemed to be the cause of low severity $(0.35)$ at fruit ripening and hence the high fruit yield (27.41) tons/ha observed in this hybrid. The negative correlation of fruit yield with disease incidence and severity at one month and at fruit ripening suggests further that fruit yield increases with decrease in disease incidence and severity. The importance of negative correlation between phenols and flavonoids with disease incidence and severity indicates that an increase in these phytochemicals leads to a decrease in disease incidence and severity. Phenols and tannins obtained from leaves of Gongronema latifolia Benth. have been reported to show direct negative effects on minimum inhibitory concentration (MIC) on Salmonella typhi which led to increased resistance to the disease (Agbo et al,. 2012). Sadasivam and Manickam, 1992 had earlier implicated phenol in offering resistance to plants. Phytochemical extracts of some plants have also been shown to be sensitive against microbial organisms (Adegoke et al,. 2009; Kaur and Arora, 2009; Doherty et al,. 2010).

The negative significant heterosis is desirable in disease severity because it indicated that such disease is more severe in the parents than was observed in the hybrids and such negative heterosis has been reported by (Kumar, et al. 2009) in tomato. The high negative $\mathrm{BPH}$ for disease incidence and severity at fruit ripening observed in all the hybrids having the wild as one of its parents is an expression of hybrid vigour (Perez, et al. 2009) and showed that the hybrids were able to resist/ tolerate the disease than the better parent (Wild). The positive $\mathrm{BPH}$ observed in the hybrid, $\mathrm{W} \times \mathrm{P}$ for phenol showed that the hybrid contains more phenol than the parent with the highest phenol content (Petomech).

The positive indirect effect of phenol through flavonoids and disease severity could be the cause of high correlation of phenol with fruit yield (Singh and Chaudhary, 1979; Agbo and Obi, 2005).

The high negative direct effect of phenol to fruit yield indicated that high level of phenol does not directly translate to high fruit yield rather, high level of phenol 
in leaves caused high resistance to leaf spots in the crop species and hence the high positive magnitude of indirect effect of phenol to fruit yield through disease severity at fruit ripening stage. The results are in agreement with the reports of Sadasivam and Manickam (1992); Kondo and Kawashima (2000), that phenol offers resistance to plants against microbes. Flavonoids shown to influence transport of auxins (Buer $e t a l$. 2010) in plants showed equal magnitude of direct and indirect effects through severity at ripening to fruit yield. The involvement of flavonoids in the transport of auxins and its synthesis as a result of infection in plants may be the cause of the direct and indirect effects of flavonoid on increased fruit yield in the study. High magnitude of direct effects caused by number of fruits/plant to fruit yield could be as a result of high positive indirect effect of that trait to yield through severity at ripening. This indicated that hybrids that have the wild as one of its parent had high magnitude of number of fruits /plant as well as high resistance to the leaf spot disease. Both traits probably translated to high fruit yield. The high number of fruits in some hybrids with wild as the pistillate might have been as a result of linkage drag that occurs when wild species are used as sources of desirable genes such as for disease resistance (Acquaah, 2007). In this case ,however, the dragged gene(s) for high number of fruits became advantageous as the fruit sizes were relatively higher than the wild species (data not shown) and further increased yield. The incidence of leaf spot disease at ripening stage with highest positive direct effect of 3.34 showed that the incidence caused less harm to the productivity of the hybrids. Such hybrids tolerated the disease symptoms, hence the high fruit yield. Traits with positive direct effect on yield showed that selection for these traits might be effective and there is possibility of improving yields in plant through selection of such characters (Ghosh et al.,. 2010).

\section{CONCLUSION}

The disease incidence and severity amongst the hybrids were significantly reduced in all cases where the wild was the pistillate parent relative to others. Such hybrids expressed heterotic effects in disease severity and fruit yield. The hybrid, W x P showed significantly higher phenol content of $4.29 \mathrm{mg} / 100 \mathrm{~g}$ as well as high negative BPH of $-30.4 \%$ in disease severity. Flavonoid showed high magnitude direct effect of 0.98 while phenol had the highest negative indirect effect of -1.79 to fruit yield. Higher level of flavonoids and phenol in the hybrids, W x P and W x In may be the cause of heterotic increase in fruit yield in them as those phytochemicals reduces severity of leaf spot and increase yield potential, respectively. The two hybrids could be selected as they had less leaf spot symptom, severity and higher fruit yield.

\section{REFERENCES}

Acquaah, G. 2007. Plinciples of Plant Genetics and Breeding. Blackwell Publishing . USA. 584PP.

Adegoke, A.A, Adebayo-Tayo, B.C. 2009. Antibacterial activity and Phytochemical analysis of leaf extracts of Lasienthera africanum. African Journal of Biotech. 8:7780.

Agbo, C. U., Obi, I.U. 2005. Yield and yield component analysis of twelve upland rice genotypes. Jour of Agric., Food, Envn and Exten. 4:29-33.

Agbo, C.U., Jaime A. Teixeira DA S., Aleke, F.I. 2011. Selection of Gongronema latifolia hybrids exhibiting heterosis for certain vitamins and lycopene. Journ. of Crop Improvement. 25: 742-755.

Agbo, C.U., Okechukwu, E.C., Jaime A. Teixeira da S., Eze, E.I. 2012. Gongronema latifolia clones: Genetic effects on some phytochemical composition and anti-microbial activity against Salmonella typhi. Dynamic Biochemistry, Process Biotechnology and Molecular Biology. 6: 95-101.

Anonymous, 2014. Cercospora leaf spot of Ligustrum. Clemenson University, S.C.Publ Service Activities. 130 Lehotsky Hall, Clemson, SC 29634-0101.

Boham, B.A., Kocipai, A.C. 1974. Flavonoids and condensed Tannins from leaves of Hawaiian Vacinium vaticulatum and $V$. calyinium. Pacific Science. 48: 458-463.

Brooklyn Botanic Garden. 2000. Natural disease control: A common-sense approach to plant first aid. Handbook \# 164. 1000 Washington Avenue, Brookyln, NY.

Buer, C.S., Imin, N., Djordjevic, M.A. 2010. Flavonoids: New Roles for Old Molecules. J. Integrative Plant Biol. 52: 255-260.

Cohen, R., Edelsdein, M., Pivonia, S., Gamliel, A., Burger, Y., Katan, J., 2000. Toward management of Monosporascus wilt of melons in Israel. Plant Disease. 84, 496- 505.

Cooke, B. M., 1998. Disease assessment and yield loss. In Jones (Ed). The Epidemiology of Plant Disease. Kluwer Publishers, Dordrecht, The Netherlands, pp 42- 71.

Dharmatti, P. R., Kulkarni, G. P., Patil, R. V., 2006. Heterosis for yield and bacterial wilt incidence in tomato. J. Asian Hort., 2(3), 151-154.

Dewey, D. R., Lu, K. H., 1959. A correlation and path coefficient analysis of components of crested wheat grass seed production. Agron J. 75, 153155. 
Doherty, V.F.,Olaniran, O.O.,Kanife, U.C. 2010. Antimicrobial activities of Aframomum melegueta. International Journ of Biology. 2:126-131.

Edinger, M.S., Watter, J.K., Furlanetto, T.W. 2008. Tomato Paste and Benign Prostrate Hyperplasia. In: Preedy, V.R., and Watson, R.R.(eds.). Tomatoes and tomato Product; Nutritional, Medicinal and Therapeutic properties. Science Publishers. U.S.A. 411-428.

Elliott, M.L.,Harmon, P.F. 2011. Cercospora leaf spot. Florida Cooperative Extension Service, Institute of Food and Agricultural Sciences. University of Florida. SS-PLP-57.

Erinle, I.B. 1979. Tomato Disease in Northern State of Nigeria. Agricultural Extension and Research Liaison Services, A.B.U, Zaria. Agric. Extension Bulletin. 31: 12-15.

GENSTAT. 2007. Genstat discovery editio 3.0. Herfordshire, UK:Lawes Agricultural Trust Rothamsted Experimental Station.

Ghosh, K. P., Islam, A. K. M. A., Main, M. A. K., Hossain, M. M., 2010. Variability and character association in F2 segregating population at different commercial hybrids of tomato (Solanum Lycopersicon L). J . Applied . sci. Environ .manage. 14 (2), $91-95$.

Harbone, J.B. 1991. Phytochemical Methods (2nd Ed.). Chapman and Hall, Hong Kong. p.8.

Hessayon, D. G., 1985. Tomato Outdoor. Expert Book Publ. UK.

Kaur, G.J., Arora, D.S. 2009. Antibacterial and phytochemical screening of Anethum graveolens, Foeniculum vulgare and Trachyspermum ammi. BMC Complementary and Alternative Medicine. 9:30-33.

Kondo, N., Kawashima, M. 2000. Enhancement of tolerance to oxidative Stress in Cucumber (Cucumis sativus L.) seedlings by UV-B irradiation: Possible involvement of Phenolic Compounds and Antioxidant enzymes. J. Plant Research. 113: 311-317.

Kumar, Y. K. H., Patil, S. S., Dharmatti, P.R., Byadagi, A.S., Kajjidoni, S.T., Patil, R. H., 2009. Estimation of heterosis for Topovirius resistance in tomato. Karnataka J. Agric Sci. 22(5), 10731075.

Lavanya, C., Vijaykumar, R., Sitadevi, B. 1997. Evaluation of rice hybrids in varying environments. Int. Rice Res. Notes. 22: 15.

Naika, S., Joep van Lidt de J., Marja de G., Martin, H., Barbara van D. 2005. Cultivation of tomato( production,processing and marketing). [Ed. Barbara van D.]. Agromisa Foundation and CTA, Wageningen, Netherlands.93p.
Obi, I. U., 2002. Statistical Methods of Detecting Differences between Treatment Means and Research Methodology Issues in Laboratory and Field Experiments. AP Express Publishers Limited Nsukka - Nigeria 117p.

Pearson, D. A., 1976. The Chemical Analysis of Foods. $\left(7^{\text {th }}\right.$ ed) Churchill and living stone, Eduinburgh, London pp 355 - 356.

Perez, P.T., Cianzo, S.R., Palmer R.G. 2009. Evaluation of soybean [Glycine max.(L.) marr.] hybrids. J.Crop Improv. 23:1-18.

Sadasivam, S., Manickam, A., 1992. Biochemical Methods for Agricultural Sciences. Wiley Eastern Limited, New Delhi and Tamil Nadu Agricultural University, Coimbatore, 178-188.

Sharma, D. K., Chaudhary, D. R., Pandey, D. P., 2001. Studies on hybrid vigour in tomato (Lycopersicon esculentum Mill.). Haryana J. Horti. Sci. 30 (3-4), 236-238.

Singh, R.K.,Chaudhary, B.D. 1979. Biometrical Methods in Quantitative Genetics Analysis. 2nd Ed. Kalyyari Pub. Ludhiana, India, pp.70-99.

SPSS for Windows. (2001). Standard Version (8). SPSS INC. London.

Tarr, S.A.W., 1981. The Principles of Plant Pathology. Macmillan press. London. pp 632

Uguru, M. I., Atugwu, A. I., 2001. Comparative study on the somatic chromosome number, growth,yield and disease incidence of cultivated tomatoes and their wild relatives. Agro-science 1(2), 52- 58.

Uguru, M. I., Igili, D. I., 2002. Field reactions of segregating population of interspecific hybrids of Lycopersicon species to natural infection by $\mathrm{x}$ anthomonas camprestris vesicatria (Doidge) Dye. Nigerian Journal of Horti. sci. 6 (1), 5-11.

Weerakkody, W. A. P., Peiris, B. C. N., 1997. Effect of Rainfall during Growth and Flowering of Tomato. In Proc. Fifth Annual Staff Ressessions, Faculty of Agriculture, University of Peradeniya Sri Lanka. 39- 41.

Wittstock, U., Gershenzon, J. 2002. Constitutive Plant Toxins and their role in defense against Herbivores and Pathogens. Elsevier Science Ltd. 1-8.

Wokoma, E. C. W., 2008. Preliminary Report on Diseases of Tomato in Choba, Rivers State J. Appl. Sci. Environ. Manage. Vol. 12(3), 117 121.

Yang C. Y., 1978. Bacteria and fungi disease of tomato. Proceedings of the $1^{\text {st }}$ International symposium on tropical tomato held in Taiwan. 9:111 
